\title{
EVALUASI HASIL BELAJAR MENGGAMBAR DAN MENDESAIN MESIN ANTARA TARUNA DARI INPUT SMA DAN INPUT SMK DENGAN METODE KELOMPOK-KELOMPOK KECIL JURUSAN TEHNIKA DI PIP SEMARANG
}

\author{
Dwi Prasetyo \\ Dosen Program Studi Teknika PIP Semarang
}

\begin{abstract}
The purpose of this study was to determine the evaluation of learning outcomes Engineering Drawing and Design between cadets of Input SMA and SMK Input Method Small Group Programs Technical in PIP Semarang. The results of this study it can be concluded that there are differences in the evaluation of learning outcomes between drawing and designing machines SMA Cadets input and input from SMK with a small group of subjects Technical method in PIP Semarang. The average value for the experimental group 1 (input from SMA) is 74.2, while the average value for the experimental group 2 (input from SMK) is 76.7. This means learning outcomes experimental group 2 was better than the experimental group 1. But overall learning outcomes Youth in drawing and designing the engine is increased.
\end{abstract}

Keywords : learning outcomes, drawing and machine design, high school and vocational school cadets input, small group

\section{PENDAHULUAN}

Salah satu tugas pokok lembaga pendidikan (dalam hal ini kampus / Politeknik Ilmu Pelayaran (PIP) Semarang) adalah menyiapkan Mahasiswa yang dimaksud adalah Taruna agar dapat mencapai perkembangannya secara optimal. Seorang taruna dikatakan telah mencapai perkembangannya secara optimal apabila taruna dapat memperoleh pendidikan dan hasil belajar yang sesuai dengan bakat, kemampuan dan minat yang dimilikinya. Terkait dengan dunia pendidikan, untuk menciptakan manusia yang berkualitas dan berprestasi tinggi maka taruna harus memiliki prestasi atau hasil belajar yang baik. Prestasi atau hasil belajar merupakan tolok ukur maksimal yang telah dicapai Taruna setelah melakukan perbuatan belajar selama waktu yang telah ditentukan bersama.
Dalam suatu lembaga pendidikan, hasil belajar merupakan indikator yang penting untuk mengukur keberhasilan proses belajar mengajar. Tinggi rendahnya hasil belajar Taruna banyak dipengaruhi oleh faktor-faktor lain di samping proses pengajaran itu sendiri (Arikunto, 1999). Salah satu faktor yang penting yang bisa mempengaruhi hasil belajar Taruna adalah metode pembelajaran yang digunakan oleh pengajar (dalam hal ini dosen).

Dalam pembelajaran di kelas, dosen sebagai pendidik, pengajar dan pengelola pendidikan bisa menggunakan berbagai sumber dan alat/bahan mata kuliah serta menggunakan berbagai metode mengajar. Apabila semua isi materi pembelajaran dari sumber yang tertuang di dalam kurikulum disampaikan dosen kepada taruna dalam kurun waktu yang singkat, maka tentu saja sangat sulit bagi Taruna untuk menguasainya dalam kurun waktu 
Dwi Prasetyo

yang terbatas pula. Kesulitan tersebut berkenaan dengan usaha untuk memenuhi ide-ide pokok, konsep-konsep, asumsi, teori dan materi yang diajarkan, termasuk juga untuk mengingat kembali materi perkuliahan yang diberikan. Sehingga untuk memudahkan dan menyesuaikan cara menyampaikan materi pembelajaran dan isi materi perkuliahan tersebut kepada Taruna, maka dosen diharapkan bisa menggunakan berbagai metode pengajaran atau metode pembelajaran (Romizowski, 1981).

Metode pembelajaran adalah cara yang teratur dan terpikir secara baik untuk mencapai maksud dan tujuan pembelajaran atau cara kerja yang bersistem untuk memudahkan pelaksanaan kegiatan belajar mengajar guna mencapai tujuan yang diharapkan. Metode pembelajaran dapat memberikan kemudahan kepada Taruna untuk menerima dan menyerap materi perkuliahan. Metode pembelajaran bisa berfungsi untuk memberikan pernyataan singkat dan rangsangan yang khusus mengenai isi bidang studi yang telah dipelajari, dan contoh-contoh acuan yang mudah diingat untuk setiap konsep, prosedur, atau prinsip yang dipelajari (Snellbecker, G.E., 1984).

Dalam studi ini penelitian akan dilakukan pada Taruna di PIP Semarang, terutama Taruna dari input Sekolah Menengah Atas (SMA) dan input Sekolah Menengah kejuruan (SMK). Berdasarkan hasil pengamatan peneliti, bahwa dalam pelaksanaan pembelajaran di kelas, khususnya dalam pembelajaran mata kuliah gambar dan desain mesin, para Taruna masih memiliki kesulitan dalam bidang mata kuliah tersebut. Hal ini disebabkan karena pengajar atau dosen yang mengajar masih menggunakan metode ceramah atau sering disebut metode konvensional yang berjalan satu arah atau monoton. Metode ceramah ini ternyata menyebabkan para taruna tersebut merasa bosan dan tidak tertarik dengan kegiatan pembelajaran yang sedang berlangsung. Mereka merasa bahwa dengan metode ceramah, mata kuliah gambar dan desain mesin adalah menjadi mata kuliah yang membosankan, melelahkan, dan tidak menyenangkan. Selain itu, mereka justru merasa kesulitan untuk mulai menggambar dan mendesain mesin sehingga mereka menjadi pasif dan kurang kreatif dalam menuangkan gagasan-gagasannya, dan ini berdampak pada hasil belajar mereka yang kurang optimal. Rata-rata nilai Taruna dari input SMA hanya sekitar 70 dan rata rata nilai Taruna dari input SMK adalah sekitar 75 .

Penggunaan metode secara baik dan tepat dapat mengatasi dan memperkecil kesulitan-kesulitan yang dihadapi Taruna dalam memahami atau mencermati materi yang disajikan dalam setiap proses pembelajaran. Melihat pentingnya penggunaan metode pada setiap proses pembelajaran seperti yang telah dikemukakan di atas, maka dalam penelitian ini mencoba mengkaji mengenai metode kelompok-kelompok kecil di dalam proses pembelajaran, khususnya menyangkut mata kuliah Gambar dan Desain Mesin. Metode kelompok kecil adalah suatu metode mengajar yang digunakan oleh dosen untuk membimbing Taruna dalam belajar secara kelompok dengan jumlah berkisar antara 3 sampai 5 orang atau paling banyak 8 orang untuk setiap kelompoknya (Tubbs, 1992). Dengan penggunaan metode kelompok kecil ini diharapkan dapat membantu Taruna yang belum bisa memahami materi pembelajaran, baik konstruksi, jenis, fungsi, dan gambar atau desain bagianbagian mesin. Dengan metode ini diharapkan pula bisa memberikan kemudahan dalam pemahaman materi yang disajikan tersebut. 
Dari uraian di atas maka peneliti tertarik untuk meneliti lebih lanjut mengenai "Evaluasi Hasil Belajar Menggambar dan Mendesain Mesin antara Taruna dari Input SMA dan Input SMK dengan Metode Kelompok Kecil Jurusan Tehnika di PIP Semarang."

Berdasarkan uraian yang telah dijelaskan sebelumnya maka rumusan permasalahannya adalah: Bagaimana Evaluasi Hasil Belajar Menggambar dan Mendesain Mesin antara Taruna dari Input SMA dan Input SMK dengan Metode Kelompok Kecil Jurusan Tehnika di PIP Semarang?

Adapun tujuan penelitian ini adalah untuk mengetahui Evaluasi Hasil Belajar Menggambar dan Mendesain Mesin antara Taruna dari Input SMA dan Input SMK dengan Metode Kelompok Kecil Jurusan Tehnika di PIP Semarang.

Hasil atau prestasi merupakan suatu hal yang telah dicapai seseorang ketika mengerjakan tugas atau kegiatan tertentu. Hasil belajar adalah penguasaan pengetahuan atau keterampilan yang dikembangkan oleh mata kuliah yang lazimnya ditunjukkan dengan nilai tes atau angka nilai yang diberikan oleh pengajar (dalam hal ini dosen) (Tulus, 2004). Dari pengertian tersebut dapat dipahami bahwa hasil belajar adalah kemampuan seseorang pada bidang tertentu dalam mencapai tingkat kedewasaan yang langsung dapat diukur dengan tes. Penilaian dapat berupa angka atau huruf.

Gambar dan desain mesin merupakan salah satu mata kuliah yang harus diambil oleh Taruna pada Jurusan Tehnika di PIP Semarang. Gambar dan desain mesin terdiri atas 3 SKS, yakni 1 SKS berupa teori dan 2 SKS berupa praktek. Tujuan kurikulum ini adalah setelah Taruna mengikuti perkuliahan, mereka mampu memahami teori gambar dan menggambar 2191 bagian-bagian mesin. Sementara itu tujuan pembelajaran umum dari mata kuliah ini adalah Taruna diharapkan dapat menjelaskan bagian-bagian mesin, sedangkan tujuan pembelajaran khususnya adalah Taruna diharapkan dapat menjelaskan tentang konstruksi, jenis, fungsi, bahan, dan gambar yang terdiri berbagai jenis mesin (PIP Semarang, 2013).

Taruna selain sebagai makhluk individu juga sebagai makhluk sosial. Sebagai makhluk individu, Taruna dapat belajar secara mandiri. Namun karena taruna juga masih dalam proses pertumbuhan dan perkembangan serta masih dalam taraf berpikir konkrit, maka hal ini perlu bantuan atau bimbingan dosen dalam proses pembelajarannya. Demikian pula dosen dalam memberikan bimbingan belajar mengupayakan adanya media atau alat peraga agar mudah dipahami Taruna baik dalam mengajar perorangan maupun kelompok kecil.

Sebagai makhluk sosial, Taruna akan bertumbuh dan berkembang dengan baik dalam belajarnya jika berada dalam suatu kelompok. Kelompok belajar yang efektif dan efisien adalah adalah kelompok belajar dalam jumlah kecil. Kelompok kecil dapat memungkinkan semua anggotanya terlibat secara aktif dalam belajar, dibawah bimbingan dosen. Demikian dosen juga dengan mudah dapat mengarahkan atau memberikan pelayanan dengan baik terhadap kelompok-kelompok tersebut. Untuk itu seorang dosen dituntut memiliki metode atau cara mengajar kelompok kecil, disamping mengajar perorangan. Metode Kelompok kecil adalah cara dosen membimbing Taruna dalam belajar secara kelompok dengan jumlah berkisar antara 3 hingga 5 orang atau paling banyak 8 orang untuk setiap kelompoknya (Tubbs, 1992). 
Dwi Prasetyo

Kerangka berpikir penelitian ini

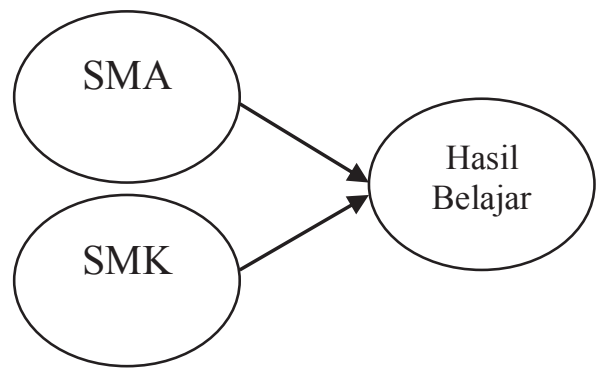

Metode pembelajaran bisa berfungsi untuk memberikan pernyataan singkat dan rangsangan yang khusus mengenai isi bidang studi yang telah dipelajari, dan contoh-contoh acuan yang mudah diingat untuk setiap konsep, prosedur, atau prinsip yang dipelajari (Snellbecker, G.E., 1984).

Berdasarkan penjelasan tersebut, maka dalam penelitian ini diusulkan dengan menggunakan metode yang tepat dan yang sesuai dengan materi yang disajikan. Melihat pentingnya penggunaan metode pada setiap proses pembelajaran seperti yang telah dikemukakan di atas, maka dalam penelitian ini mencoba mengkaji mengenai metode kelompok-kelompok kecil di dalam proses pembelajaran, khususnya menyangkut mata kuliah Gambar dan Desain Mesin. Metode kelompok kecil adalah suatu metode mengajar yang digunakan oleh dosen untuk membimbing Taruna dalam belajar secara kelompok dengan jumlah berkisar antara 3 sampai 5 orang atau paling banyak 8 orang untuk setiap kelompoknya (Tubbs, 1992). Dengan penggunaan metode kelompok kecil ini diharapkan dapat membantu Taruna yang belum bisa memahami materi pembelajaran, baik konstruksi, jenis, fungsi, dan gambar atau desain bagian-bagian mesin. Dengan metode ini diharapkan pula bisa memberikan kemudahan dalam pemahaman materi yang disajikan tersebut.

Selanjutnya hipotesis yang diajukan adalah: Terdapat perbedaan evaluasi hasil belajar menggambar dan mendesain mesin antara Taruna dari input SMA dan input SMK dengan metode kelompok kecil Jurusan Tehnika di PIP Semarang.

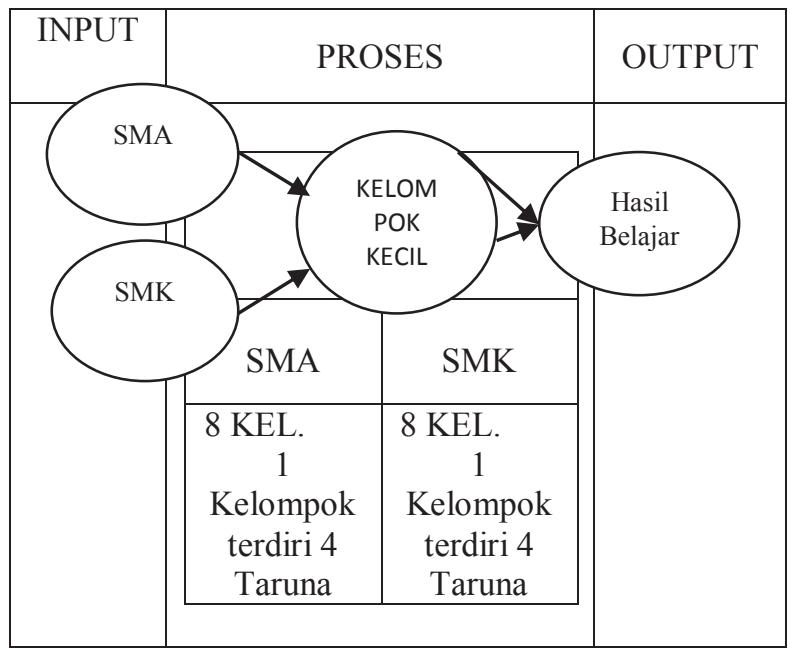

\section{METODE PENELITIAN}

Desain dalam penelitian ini menggunakan pretest-posttest control group design untuk menguji signifikansi pengaruh suatu perlakuan / treatment yang diuji cobakan. Pretest-posttest control group design adalah desain penelitian eksperimen dengan menggunakan dua kelompok, yaitu kelompok eksperimen I (Taruna dari Input SMA) dan kelompok eksperimen 2 (Taruna dari Input SMK) yang didahului dengan pretest dan diakhiri posttest (Sugiono, 1998). Desain penelitian ini dapat digambarkan seperti berikut:

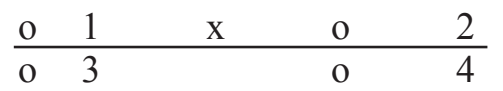

\section{Keterangan}

O1 : pretest kelompok eksperimen I

$\mathrm{O} 2$ : posttest kelompok eksperimen I

$\mathrm{X}$ : Treatment atau perlakuan

$\mathrm{O} 3$ : pretest kelompok eksperimen 2

$\mathrm{O} 4$ : posttest kelompok eksperimen 2

Desain penelitian eksperimen yang digunakan adalah sebagai berikut: 


\begin{tabular}{|c|c|c|c|}
\hline Kelompok & Pre-test & Perlakuan & Post-test \\
\hline KE I & $\mathrm{K}-1$ & $\begin{array}{c}\text { Model } \\
\text { Kelompok } \\
\text { Kecil }\end{array}$ & $\mathrm{K}-2$ \\
\hline KE 2 & $\mathrm{~K}-1$ & & $\mathrm{~K}-2$ \\
\hline
\end{tabular}

Keterangan :

KE I : Kelompok

Eksperimen I

KE 2 : Kelompok K-2 : Post Test

Eksperimen 2

Populasi dalam penelitian eksperimen ini, yang menjadi populasi adalah keseluruhan subjek penelitian yaitu Taruna dari input SMA dan Taruna dari input SMK di PIP Semarang yang berjumlah 128 Taruna. Sedangkan pengambilan sampel ditetapkan sebesar $25 \%$ dari populasi, yaitu $128 \times 25 \%=32$ responden (dalam hal ini 32 responden dari input SMA dan 32 responden dari input SMK).

Teknik pengambilan sampel yang digunakan dalam penelitian ini adalah purposive sampling atau sample bertujuan secara subyektif. Teknik ini dilakukan karena peneliti telah mendapatkan informasi yang dibutuhkan dari dua kelompok yang memenuhi kriteria yang ditentukan oleh peneliti, yakni kelompok 1 (Taruna dari input SMA) dan kelompok 2 (Taruna dari input SMK).

Variabel dalam penelitian ini adalah terdiri atas variabel bebas, yakni metode kelompok kecil dan variabel terikat, yakni hasil belajar. Instrumen penelitian yang digunakan dalam penelitian ini adalah berupa tes dan non tes. Metode yang digunakan untuk mengumpulkan data dalam penelitian ini adalah metode tes, dan metode observasi. Teknik analisis data yang digunakan dalam penelitian ini adalah uji normalitas, uji homogenitas, dan uji t.

\section{HASIL PENELITIAN DAN PEMBAHASAN}

Hasil penelitian dapat dilihat dari hasil belajar ini adalah hasil dari kelompok eksperimen 1 dan kelompok eksperimen 2, serta perbedaan keduanya. Dengan perbedaan hasil belajar kedua kelompok tersebut, akan terlihat pengaruh penggunaan metode kelompok kecil dalam menggambar dan mendesain mesin Jurusan Tehnika di PIP Semarang. Secara lengkap akan dijabarkan sebagai berikut:

1) Hasil Belajar Kelompok Eksperimen 1 Berdasarkan tes setelah pembelajaran mata kuliah Gambar dan Desain Mesin maka diperoleh hasil sebagai sesuai dengan data yang diperoleh pada tabel.

Dari tabel di bawah ini, akan dapat dilihat bahwa nilai rata-rata kelas eksperimen 1 dalam menggambar dan mendesain dengan metode kelompok kecil adalah 74,2 atau kategori cukup. Dari keseluruhan Taruna yang mendapat skor 85 atau kategori baik ada 3 orang atau $9,4 \%$, skor 80 atau kategori agak baik ada 4 orang atau $12,5 \%$, skor 75 atau kategori cukup ada 14 orang atau $43,8 \%$, skor 70 atau kategori kurang baik ada 7 orang atau $21,9 \%$, dan skor 65 atau kategori tidak baik ada 4 orang atau 12,5\%. 
Dwi Prasetyo

Tabel 1. Hasil Tes Akhir Kelompok Eksperimen 1

\begin{tabular}{|c|c|c|c|c|c|c|}
\hline No & $\begin{array}{c}\text { Kateg } \\
\text { ori }\end{array}$ & Skor & $\begin{array}{l}\text { Frek } \\
\text { uensi }\end{array}$ & $\begin{array}{l}\text { Bobot } \\
\text { Skor }\end{array}$ & $\begin{array}{c}\text { Perse } \\
\text { ntase } \\
(\%)\end{array}$ & $\begin{array}{l}\text { Rata- } \\
\text { rata }\end{array}$ \\
\hline 1. & Baik & 85 & 3 & 255 & 9,4 & \multirow{6}{*}{$\begin{array}{c}\frac{2375}{32} \\
= \\
\mathbf{7 4 , 2}\end{array}$} \\
\hline 2. & $\begin{array}{l}\text { Agak } \\
\text { Baik }\end{array}$ & 80 & 4 & 320 & 12,5 & \\
\hline 3. & Cukup & 75 & 14 & 1050 & 43,8 & \\
\hline 4. & $\begin{array}{l}\text { Kuran } \\
\text { g Baik }\end{array}$ & 70 & 7 & 490 & 21,9 & \\
\hline \multirow[t]{2}{*}{5.} & $\begin{array}{l}\text { Tidak } \\
\text { Baik }\end{array}$ & 65 & 4 & 260 & 12,5 & \\
\hline & & & 32 & 2375 & & \\
\hline
\end{tabular}

Sumber: Data yang diolah, 2018

2) Hasil Belajar Kelompok Eksperimen 2

Berdasarkan tes setelah pembelajaran mata kuliah Gambar dan Desain Mesin maka diperoleh hasil sebagai berikut:

Tabel 2. Hasil Tes Akhir Kelompok Eksperimen 2

\begin{tabular}{|c|c|c|c|c|c|c|}
\hline No & Kategori & Skor & $\begin{array}{l}\text { Fre } \\
\text { kue } \\
\text { nsi }\end{array}$ & $\begin{array}{l}\text { Bobot } \\
\text { Skor }\end{array}$ & $\begin{array}{c}\text { Persenta } \\
\text { se } \\
(\%)\end{array}$ & $\begin{array}{l}\text { Rata- } \\
\text { rata }\end{array}$ \\
\hline 1. & Baik & 85 & 6 & 510 & 18,8 & \multirow{6}{*}{$\begin{array}{l}2255 \\
3 \\
= \\
76,7\end{array}$} \\
\hline 2. & $\begin{array}{l}\text { Agak } \\
\text { Baik }\end{array}$ & 80 & 10 & 800 & 31,3 & \\
\hline 3. & Cukup & 75 & 9 & 675 & 28,1 & \\
\hline 4. & $\begin{array}{l}\text { Kurang } \\
\text { Baik }\end{array}$ & 70 & 3 & 210 & 9,4 & \\
\hline \multirow[t]{2}{*}{5.} & $\begin{array}{l}\text { Tidak } \\
\text { Baik }\end{array}$ & 65 & 4 & 260 & 12,5 & \\
\hline & & & 32 & 2455 & & \\
\hline
\end{tabular}

Sumber: Data yang diolah, 2018

Dari tabel di atas dapat dilihat bahwa nilai rata-rata kelompok eksperimen 2 dalam menggambar dan mendesain dengan metode kelompok kecil adalah 76,7 atau kategori baik. Dari keseluruhan Taruna yang mendapat skor 85 atau kategori baik ada 6 orang atau $18,8 \%$, skor 80 atau kategori agak baik ada 10 orang atau $31,3 \%$, skor 75 atau kategori cukup ada 9 orang atau $28,1 \%$, skor 70 atau kategori kurang baik ada 3 orang atau 9,4\%, dan skor 65 atau kategori tidak baik ada 4 orang atau $12,5 \%$.

Setelah diberikan eksperimen, data tes akhir dianalisis untuk membuktikan ada tidaknya perbedaan hasil belajar menggambar dan mendesain mesin dengan metode kelompok kecil antara Taruna dari input SMA dan input SMK di PIP Semarang. Untuk membuktikan hipotesis tersebut data terlebih dahulu diuji dengan tiga analisis yakni uji normalitas, uji kesamaan varian (homogenitas) dan selanjutnya uji kesamaan rata-rata atau t-tes.

Sedangkan dari hasil perhitungan uji normalitas pada kelompok eksperimen 1 diperoleh harga mutlak selisih yang paling besar yaitu 0,1562 . Dengan $n=$ 32 dan taraf nyata $\alpha=5 \%$ dari daftar nilai kritis untuk uji normalitas didapat $\mathrm{L}$ tabel $=0,1566$. Karena $\mathrm{L}$ hitung $<\mathrm{L}$ tabel yaitu $0,1562<0,1566$ maka sampel berasal dari populasi berdistribusi normal.

Uji normalitas pada kelompok eksperimen 2 dalam penelitian ini diperoleh harga mutlak selisih yang paling besar yaitu 0, 1419. Dengan $\mathrm{n}=32$ dan taraf nyata $\alpha=5 \%$ dari daftar nilai kritis untuk uji normalitas didapat $\mathrm{L}$ tabel $=0,1591$. Karena L hitung $<\mathrm{L}$ tabel yaitu $0,1419<0,1591$ maka sampel berasal dari populasi berdistribusi normal.

Uji homogenitas atau kesamaan varian diperoleh varian lebih besar $(\mathrm{S} 12)=25,741$ dan varian lebih kecil $(\mathrm{S} 22)=17,741$ sehingga didapatkan $\mathrm{F}$ hitung $=1,451$ dengan $\alpha=5 \%$ dan $\mathrm{dk}$ pembilang $\mathrm{n} 1-1=32-1=31$; dk penyebut $\mathrm{n} 2-1=32-1=31$. Dari perhitungan tersebut didapatkan $\mathrm{F}$ tabel $=1,822$ sehingga $\mathrm{F}$ hitung $<\mathrm{F}$ tabel, 
yakni $1,451<1,822$. Dengan demikian, varian kedua kelompok tersebut disebut homogen.

Uji kesamaan rata-rata diperoleh $\mathrm{t}$ hitung sebesar 4,3129, sedangkan untuk nilai ttabel dengan $\alpha=5 \%, \mathrm{db}=2(\mathrm{n}-1)$ $=2(32-1)=62$ diperoleh ttabel $=1,999$. Karena thitung $>$ ttabel maka ada perbedaan yang signifikan antara kelompok eksperimen 1 dengan kelompok eksperimen 2. Dari hasil uji hipotesis diperoleh simpulan bahwa Ho ditolak dan Ha diterima. Hal ini berarti bahwa hipotesis yang mengatakan terdapat perbedaan evaluasi hasil belajar menggambar dan mendesain mesin antara Taruna dari input SMA dan input SMK dengan metode kelompok kecil Jurusan Tehnika di PIP Semarang adalah diterima.

Berdasarkan hasil belajar menunjukkan bahwa pembelajaran mata kuliah Gambar dan Desain Mesin antara Taruna dari input SMA dan input SMK dengan metode kelompok kecil adalah terdapat perbedaan yang signifikan. Perbedaan hasil belajar ini disebabkan adanya perbedaan perlakuan sebelumnya pada masingmasing kelompok. Faktor-faktor lain mungkin ikut berpengaruh, tetapi faktor-faktor tersebut tidak diperhitungkan.

\begin{tabular}{|c|c|c|c|c|c|c|}
\hline \multirow{3}{*}{$\begin{array}{l}\begin{array}{l}\text { Rata- } \\
\text { rata }\end{array} \\
\text { Nilai }\end{array}$} & \multicolumn{2}{|c|}{ Kel. 1} & \multirow{2}{*}{$\begin{array}{c}\text { Perse } \\
\text { ntase } \\
(\%)\end{array}$} & \multicolumn{2}{|c|}{ Kel. 2} & \multirow{2}{*}{$\begin{array}{c}\text { Persen } \\
\text { tase } \\
(\%)\end{array}$} \\
\hline & \multicolumn{2}{|c|}{76,7} & & \multicolumn{2}{|c|}{74,2} & \\
\hline & 85 & 6 & 18,8 & 85 & 3 & 9,4 \\
\hline & 80 & 10 & 31,3 & 80 & 4 & 12,5 \\
\hline & 75 & 9 & 28,1 & 75 & 14 & 43,8 \\
\hline & 70 & 3 & 9,4 & 70 & 7 & 21,9 \\
\hline & 65 & 4 & 12,5 & 65 & 4 & 12,5 \\
\hline
\end{tabular}

Rata-rata nilai untuk kelompok eksperimen 1 adalah 74,2, sedangkan rata-rata nilai untuk kelompok eksperimen 2 adalah sebesar 76,7. Dengan demikian selisih rata-rata 2,5. Nilai rata-rata kelompok eksperimen 1 lebih rendah daripada kelompok eksperimen 2. Hasil tes tersebut menunjukkan bahwa pembelajaran mata kuliah Gambar dan Desain Mesin antara Taruna dari input SMA dan input dari SMK dengan metode kelompok kecil adalah terdapat perbedaan hasil belajar. Namun secara keseluruhan hasil belajar Taruna di PIP Semarang dalam menggambar dan mendesain mesin adalah meningkat.

\section{PENUTUP}

Berdasarkan hasil penelitian dapat disimpulkan sebagai berikut:

a) Hasil belajar kelompok 1 adalah 74,5 (cukup).

b) Hasil belajar kelompok 1 76,7 (baik).

c) Perbedaan adalah selisih 76,7 - 74,2 = 2,5.

Berdasarkan hasil penelitian ini saran yang dapat diberikan adalah:

a) Dosen hendaknya dapat mempertimbangkan penggunaan metode kelompok kecil dalam mata kuliah menggambar dan mendesain mesin.

b) Dosen hendaknya dapat lebih banyak mengaktifkan Tarunanya dalam pembelajaran melalui metode kelompok kecil, sehingga Taruna lebih mudah untuk memahami materi yang diberikan.

c) Bagi peneliti selanjutnya, diharapkan mengangkat penggunaan metode kelompok kecil sebagai tema dalam penelitian.

\section{DAFTAR PUSTAKA}

Arikunto. 1999. Manajemen Pengajaran Secara Manusiawi. Rineka Cipta

Romizowski. 1981. Designing Instructional System. Decession 
Evaluasi Hasil Belajar Menggambar Dan Mendesain Mesin Antara Taruna Dari Input SMA Dan Input SMK Dengan Metode Kelompok-Kelompok Kecil Jurusan Tehnika Di PIP Semarang

Dwi Prasetyo

Making in Course. Planning and Curriculum Design. New York: Nocolas Publishing

Snellbecker. 1984. Learning Theory, Instructional Theory, and Psychologi Educational Design. New York: Mc-Graw Hill Bork Company

Sugiono. 1998. Metode Penelitian Kuantitatif, Kualitatif, dan $R \& D$. Bandung: Alfabeta

Tubbs. 1992. A System Approach to Small Group Interaction. New York: Mc Graw-Hill, Inc

Tulus, Tu'u. 2004. Peran Disiplin pada Perilaku dan Prestasi Siswa. Jakarta: Grasindo 